\begin{tabular}{|c|c|}
\hline ב & $\begin{array}{c}\text { International Journal of Current Research } \\
\text { and Academic Review }\end{array}$ \\
\hline $\begin{array}{l}\text { EXCELLENT } \\
\text { PUBLISHERS }\end{array}$ & $\begin{array}{c}\text { ISSN: 2347-3215 (Online) Volume } 6 \text { Number } 7 \text { (July-2018) } \\
\text { Journal homepage: http://www.ijcrar.com }\end{array}$ \\
\hline
\end{tabular}

doi: https://doi.org/10.20546/ijcrar.2018.607.004

\title{
Technical Methodology for the Integral Homologation of the Public Transport of Interprovincial Buses
}

\author{
José Luis Gavidia García ${ }^{1}$, Eddy Stalin Alvarado Pacheco ${ }^{2}$ and Luis Alfonso Condo Plaza ${ }^{3 *}$ \\ ${ }^{1}$ Ingeniero Industrial, Magister en Gestión Industrial y Sistemas Productivos, Docente de la Escuela Superior \\ Politécnica de Chimborazo (2013-2018) Ecuador \\ ${ }^{2}$ Ingeniero Industrial, Magister en Gestión Industrial y Sistemas Productivos, Docente de la Universidad Estatal de \\ Bolivar (2016 - 2018) Ecuador \\ ${ }^{3}$ Ingeniero Zootecnista, Magister en Proyectos Productivos y Sociales, Docente de la Escuela Superior Politécnica de \\ Chimborazo, (2000-2018, Ecuador
}

*Corresponding author

\section{Abstract}

The integral homologation of public transportation of interprovincial buses in Ecuador was born as a response to the need to increase the safety and quality of service to users, currently only homologates the product as such, ie the BUS, without considering other aspects Important that are part of the public transportation system, such as: Administrative Management, Qualification of Drivers, Vehicle Fleet Maintenance Program and Quality of Service to the User. Technical regulations applied to interprovincial transport companies, based on the current resolution 081 DIR-2015-ANT, were drafted. Generating coordinated work between users and control agencies, such as: Ministry of Transport, National Transit Agency (ANT), Decentralized Autonomous Governments (GAD), National Commission for Land Transport, Traffic and Road Safety, the Ecuadorian Institute for Standardization INEN, among others. A diagnosis of the current situation was made on the basis of a sample of the number of interprovincial public transport companies and assessing the needs through indicators. A technical regulation model was elaborated, which allowed to improve from 51\% to 67\%. Efficiency of the Administrative Management, Driver Rating from 38\% to 47\%, Vehicle Maintenance compliance increased from $15 \%$ to $79 \%$, and User Service Quality from $38 \%$ to $50 \%$. In general, the technical regulations increased from $10.39 \%$ to $41.36 \%$, in relation to the four (4) criteria evaluated
\end{abstract}

\section{Article Info}

Accepted: 04 June 2018

Available Online: 10 July 2018

\section{Keywords}

Integral homologation; Quality of service; User; Public transport; Technical regulations; Body

\section{Introduction}

In developed countries such as Spain, Canada, Germany and others, control of the public transport service plays a preponderant role aimed at reducing pollution, increasing user safety, extending the life of vehicles and increasing user satisfaction.
The public transport service in the city of Toluca (Mexico) and its metropolitan area has structural organizational deficiencies at strategic and tactical levels, and consequently operational. In effect, the urban and metropolitan public transport policy is unclear and relevant to guide both the growth and sustainability of the urban area and its metropolitan area. On the other 
hand, there is a lack of public intervention to regulate the provision of the service and to choose the regulation scheme that guarantees an acceptable quality of service for all the actors (Flores and Torres, 2010).

Transport is an essential element not only in the life of today's cities, but also in a general way in the development of the towns, to the point that it is difficult to consider the answer to a contractual hypothesis with respect to how our cities and metropolitan areas without transportation.

Transport has always been present in human societies as a basic need for their survival, to guarantee the continuity of society (in a projection of its natural function within ecosystems) through the transfer of nutrients and waste generated (Martín, 2011). In this natural context, transport enjoys total compatibility with the environment, minimizing its impacts through a strategy to reduce mobility in which vertical movement is the most important and the horizontal is maximized (Martín et al., 2012)

In this regard the European standard on quality of urban public transport EN13816 (ECS, 2002) helps consumetodología the "circle of quality of service" Tomandoen account as a point of departure the quality desired by the customer, the supplier (authority and operator) establishes its goal of quality, considering also the good practices of the industry and the performances of the competitors (private car and motorcycle), as well as budgetary and technical restrictions (Gutierrez, 2013).

The quality with which the demand for transport is satisfied by the transportation system is called service level of travel. The level of service will produce some effects or impacts both on the users of the system and on the rest of the inhabitants (Fernandez, 2012).

The public transport of interprovincial buses has a fundamental function within the national territory, which is to provide the service of mobility of people contributing to the development of the country, so that safety and quality of service to users should not be neglected.

Currently, buses in different categories in Ecuador, are subject to the approval only of the product as such (bodywork and / or buses), but not other important aspects that are part of the overall context of the public transport service system, such as This is the case of the operating companies, the competence, training and technical training of the drivers, maintenance programs of the units, safety prevention plan, route programming, administrative management, and a quality system in the service to the user.

The companies that manufacture bus bodies give full compliance to the rules and technical regulations related to the construction of buses, and lately to the resolution 081-DIR-2015-ANT, corresponding to the homologation of the units, however there is no methodology that integrates other important aspects immersed in the system of public transport of buses especially, the homologation and validation of maintenance plans, which means that there is no programmed technical control of the units, increasing the risk of accidents due to mechanical failures, little or poor quality of service to users in the infrastructure of the offices of attention to the public as in the moments of truth, in addition to lacking a safety plan in terms of safety, efficient route planning and efficient administrative management to provide reliability to users.

In this context, the directory of the National Agency for Regulation and Control of Land Transportation, Traffic and Road Safety, informs that, in accordance with the provisions of numeral twenty-five (25) of article sixtysix (66), of the Constitution Policy of the Republic of Ecuador, it is the duty of the State to guarantee people the right to dispose of public and private goods and services of optimum quality with efficiency, effectiveness and good treatment, according to Resolution No. 081-DIR-2015-ANT.

This research work is focused on the elaboration of a technical regulation for the integral homologation of interprovincial bus public transport, through the fundamental insertion for improvement, as shown in graph No. 1.

Through the process you can obtain the unique certificate of approval for each of the aspects immersed in the transport system.

\section{Diagnosis of the current status of the homologation process}

Currently, public bus transport companies in Ecuador are subject to the current resolution for obtaining the single certification certificate. Resolution 081-DIR-2015-ANT mentions the norms and procedures for the homologation of prototype bodies for buses of the different modalities and categories, silly of national manufacture, as 
imported, accessories and safety elements that are part of a bus.

In the current resolution published at the end of 2015 and the previous ones does not mention any procedure for the homologation of other aspects immersed in the public transport system mentioned above, hence the importance of the proposal presented. NTE INEN 2 205: 2010,

For the elaboration of the technical regulations, Resolution No. 081-DIR - 2015 - ANT was taken as reference. Concerning the INEN norms and regulations in force.

The main focus of this proposal stems from the research work, which consists of designing a methodological structure of the management system for the integral homologation of other aspects that are immersed within the public transport service of interprovincial buses, the same as it is suitable for improving it public service in terms of quality management in the service and security.

In this sense, the present investigation arises in response to the bus public transport service conditions currently available in the country, due to the fact that there is no regulated program that allows the application of the comprehensive homologation norms that lead to greater safety and better quality of service. With the application of this proposal it is required to reduce accidents on the roads due to mechanical failures and provide a better quality of service to users in real moments.

The custom and the ignorance of the users means that a constant level of service is maintained for many years, where in the best of scenarios an increase in the quality of service of public bus transport can be seen, which has been greatly slowed down, which is why the academy feels the need to contribute with new ideas and solutions in the different technological fields for the good of society.

It can be observed, that here lies the importance of the present investigation and is fully justified, since if the other aspects immersed in the public bus transport system are not integrated into the homologation process, the conditions of safety and quality of service

Users will not experience a positive change for a long time, nor will the prestige of public transport companies be increased, even worse if safety and quality of service decline and accidents due to mechanical failures and / or other aspects are not reduced..
In addition, no regulations have been made that integrate into the homologation of buses in all categories, these aspects that are part of the public transport system, taking into account the impact that safety and quality of service causes.

\section{Materials and Methods}

The main focus of this research work is to design a methodological structure of the management system for the integral homologation of other aspects that are immersed in the public transport service of interprovincial buses, the same as is appropriate to achieve quality management in the service and the safety of the people who make use of this transportation system at the level of the Ecuadorian territory.

The public transport system of interprovincial buses is analyzed in the present study, taking into account as a practical case a company of the locality. It is convenient to structure the integral management system of this category of public transport, based on the reference framework, with solutions to the problems detected in the study environment and validation of hypotheses drawn.

Through the analysis of technical and regulated documents, the logic, characteristics and rules of the integral management system for interprovincial public transport are structured.

Adjustment basics are considered depending on the category of bus transport, updating of standards and continuous improvement.

\section{Procedure for the integral homologation}

\section{Section 1}

\section{Purpose}

The purpose of this procedure is to establish the requirements and procedures for obtaining the single Certificate of approval of administrative management, driver qualification, vehicle maintenance and quality of service, which would become a requirement obligatory for the normal functioning of its activities; in order to guarantee a service of quality and integrity of the users and operators.

Likewise, it establishes the control actions for compliance and sanction. 


\section{Section 2}

\section{Field of application}

The present regulation is of national observance and must be fulfilled by the applicants of the homologation process, which are:

Any natural or juridical person that offers the service, that has or possesses the legal representation of the interprovincial public bus transport company.

The current regulation will be framed to:

Administrative Management

Drivers Qualification

Maintenance of the Fleet of Vehicles

Quality of Service to the User

Homologation of the body

They are compulsorily approved before the start of their economic activity and periodically evaluated for the normal operation, all these services mentioned above and those that the competent authority considers necessary.

\section{Section 3}

\section{Homologation authority}

A Control and Regulation Body will be the institution responsible for the approval, approval, regulation and control of Integral Management. The responsibility for homologation and updates belongs to the applicant and will be subject to the sanctions determined by the Control Body.

\section{Section 4}

\section{Issuance of the single certificate of homologation}

The Executive Directorate or its delegate will sign the corresponding Single Certificate of Approval of the requested service.

The Single Certificate of Homologation must contain the identification data of the service, of the standards or specifications that have served as the basis for the homologation process, as well as the period of validity and the homologation number granted.

The Single Certificate of Homologation is delivered to the applicant and the approved product and / or service will be published on the website of the Control and Regulation Body.

\section{Section 5}

\section{Market surveillance authorities}

Market surveillance authorities will be the Land Transport Regulation and Control Bodies such as;

The National Transit Agency,

The Ecuadorian Normalization Service, and those that make up the National Quality System.

\section{Section 6}

\section{General aspects}

The process of approval of the Integral Management allows to register, validate and authorize the normal operation of the company, within the legal framework of competencies, ensuring that these comply with the requirements established within the regulatory framework of safety standards and quality of service to the user.

\section{Section 7}

\section{Terms and definitions}

For the purposes of this regulation the following terms and definitions are used.

\section{Moments of truth}

It is the physical and emotional contact between the provider and the client.

\section{User or client}

It is the person who makes use of the services provided by the provider.

\section{Company}

Structured organization that offers service to citizens.

\section{Efficiency}

Do something at the lowest possible cost. (Chase, Jacobs, \& Aquilano, 2005) 


\section{Section 8}

\section{Products to be approved}

The Integral Management of interprovincial public transport companies will be subject to homologation.

\section{Section 9}

\section{Requirement for the homologation process}

The mandatory requirements for this approval process are detailed below.

Fill out the homologation request that can be obtained on the website of the Control Agency and addressed to the highest authority thereof, which it contains.

Type of service

Name of the legal entity, or legal representative of the company

Unique taxpayer registration

Signature of the legal representative or agent

Documents attached to the application

Simple copy of the single Taxpayer Registry (RUC) issued by the SRI.

Simple copy of the citizenship card and voting ballot of the legal representative

Technical sheet for the homologation of the service, according to the current format, which may be published on the website of the designated Regulation and Control Body.

The documents must be valid at the time of presentation, which will be presented in a single ringed and digital format.

\section{Section 10}

\section{Homologation of the Service}

Integral Management, object of the homologation process must comply with the provisions of this document, duly demonstrated before a designated or accredited body in Ecuador, which will issue a report evaluating compliance with the aforementioned regulation.

\section{Section 11}

\section{Procedure}

Individuals or legal entities, must gather all the documentation described in section nine (9), and directed to the highest authority of the Regulation and Control Body. The documentation will be verified within a term not exceeding five (5) days; If it complies with all the requirements, the Regulation Office will require the applicant within a maximum period of two (2) days to start the evaluation process before a designated or accredited body, which will send the evaluation report to the Regulatory Directorate.

Printed and digital format. If there is a breach of article nine (9), within a term of two (2) days, the Directorate of Regulation and Control will notify the applicant to correct the disagreement, for which the applicant will have a maximum period of ten (10) days for remedy the lack otherwise the request will be considered abandoned.

\section{Section 12}

\section{Homologation of updates}

If a homologation has been obtained for a base service and you want to approve an update that has not been approved in the original process, you must carry out the process of homologation of the update, for which you must comply with the provisions of sections nine (9), ten (10) and eleven (11) of this document.

\section{Section 13}

\section{Responsibility}

The quality or status of the homologated service does not exempt the applicant from the responsibilities incurred if they do not comply with that of the approved service.

\section{Section 14}

\section{Documentation}

The documentation that will serve as the basis for the approval process will be available at all times to the applicant and the control bodies with due guarantees of security and confidentiality. 


\section{Later controls}

\section{Section 15}

\section{Control operations}

The Regulation and Control Body may verify the conditions of the approved service when it deems it necessary without the need for authorization by the applicant or accredited entity.

\section{Section 16}

\section{Revocation of the single certificate of homologation}

The single type approval certificate may be revoked by the Executive Director of the Regulation and Control Body, after notifying the applicant of the homologation, if the Control Body detects by any means a breach of the following aspects:

Non-compliance with the approved aspects.

Issue users a level of service lower than the level of service approved.

When the application is different from the approval conditions. When nonconformities are detected that were not declared by the applicant during the homologation process. When the applicant refuses to perform audits of the specifications to which the approval certificate was granted. When an approved product or service was modified and affected the service specifications object of homologation.

Public transport companies of interprovincial buses, which fail to comply with the provisions of these regulations, will be subject to the sanctions provided for in the Organic Law of Land Transportation, Traffic and Road Safety, the Law of the Ecuadorian Quality System and other laws in force, according to the physical and emotional risk that it implies for the users and the seriousness of the breach.

\section{Sanctioning procedure}

\section{Section 17}

\section{Procedure}

The revocation of the homologation must be supported by administrative procedure, which may be in charge of the Legal Advice Department of the Regulation and Control Body.

The substantiation must begin with the written notification to the alleged offender of the facts investigated or reported, who will have seven (7) days to make the necessary justifications; and it will conclude with a report issued by the Legal Advice Directorate to the petitioner, which must include the conclusions derived from the research supported and the respective recommendations.

\section{Section 18}

\section{Provisional measures}

The Office of Legal Advice within the period of the Sanction, may issue provisional measures such as, call for attention in writing, and / or a fine at the discretion of the Competent Authority, until a final decision.

\section{Section 19}

\section{Definitive measures}

It may reach the definitive revocation of the homologation, when the applicant company does not comply with the proposed provisions to improve the service and provide greater security to users, for more than two consecutive infractions.

It is worth mentioning that the present proposal may be adjusted to any other category of public bus transportation nationwide.

Within the public transport system of interprovincial buses, an analysis of the administrative management, driver qualification, vehicle maintenance and quality of service was developed, through an audit of compliance with these aspects, giving a percentage of unsatisfactory compliance, since that within the homologation vehicular these aspects are not evaluated immersed in the system of public transport of buses in Ecuador. The results were analyzed with the Chi squared fit test to check the hypothesis (Table 7).

The instrument designed for data collection was a CheckList (Table 2) applied in six (6) interprovincial companies determined in the sample, which contains the parameters that must be quantified to establish a level of compliance of the different aspects of the integral homologation. Table 1 shows the qualification criteria. 
The application of the CheckList allowed verifying the level of compliance with the aspects considered as part of interprovincial public transport management. Table 2 shows the qualification criteria.

The CheckList model was presented to raise information about the existing maintenance plans. Structure that was applied for the four (4) aspects considered.

\section{Population and sample}

Population: Corresponds to the number of public transport companies of interprovincial buses nationwide, within which are different modalities and categories, so for the modality of interprovincial buses we have three categories, A - AA and AAA, according to its characteristics, according to the ANT; of which category AA was taken for the calculation of the sample

Sample:

For the calculation of the sample the following formula was used, (Moore, 2005):

$$
n=\frac{Z^{2} p q N}{\mathrm{Nk}^{2}+Z^{2} p q}
$$

Where:

\author{
$\mathrm{N}$ : Population Size (166 Companies) \\ $\mathrm{Z}$ : Confidence level $(90 \%=1.64)$ \\ K: Sample error acceptance limit $(20 \%=0.2)$ \\ p: Acceptance level (0.5) \\ q: Rejection level (1-p): 0.5 \\ $\mathrm{n}$ : Size of the sample to be determined.
}

The calculation of the sample for interprovincial transport companies is:

$$
\begin{aligned}
& n=\frac{(166)(1,64)^{2}(0,5)(0,5)}{(166)(0,2)^{2}+(1,64)^{2}(0,5)(0,5)} \\
& n=15 \text { Compañias }
\end{aligned}
$$

Fifteen (15) interprovincial public transport companies are considered for the analysis (Table 3 ).

\section{Vehicle maintenance}

The proposal to develop and apply a Vehicle Maintenance Plan not only favors the conservation of transport units, but also guarantees the integrity of the users during their mobilization.
With an optimal control and regulation of maintenance of buses, aims to reduce the accident rate due to mechanical failures, so it proposes the following aspects:

Scheduled vehicle maintenance plan for 100 thousand kilometers

Have qualified service workshops where you can have a spare parts center, quality control of maintenance, calibrated tools, etc.

Agreements with qualified service workshops

Record of maintenance of the vehicular fleet

Compliance evaluation indicators

With the tabulated data, the current situation of compliance with vehicle fleet maintenance is determined

In this way $76 \%$ of non-compliance is observed, which provides ample opportunity for improvement in this aspect (Table 4-6).

\section{Administrative management}

To evaluate the Administrative Management information of the following parameters was raised.

Route plans

Efficient parcel service

Procedures of human talent

Statute of the Transport Cooperative

Internal Regulations of the Company

Quality Policy

Mission

Vision

Values

Compliance indicator according to internal policy

Human talent training plan

Organizational structure

License, vacation and permit process

Computer equipment (hardware - software)

\section{Drivers qualification}

To evaluate the performance of the drivers, the following information was collected.

Functions defined according to organism

Education

Training 
Table.1 Qualification criteria for evaluation

\begin{tabular}{|l|l|c|}
\hline ACRONYM & \multicolumn{1}{|c|}{ GRADING CRITERIA } & $\begin{array}{c}\text { WEIGHT } \\
(\%)\end{array}$ \\
\hline NC & Does not Comply (No information is evidenced) & $0 \%$ \\
\hline MC & $\begin{array}{l}\text { Medium Compliance (available, but not implemented, } \\
\text { there is little evidence and partial records) }\end{array}$ & $50 \%$ \\
\hline AC & $\begin{array}{l}\text { High compliance (It is available, it is applied in } \\
\text { accordance with the established norms, with results, } \\
\text { records and evidences) }\end{array}$ & $100 \%$ \\
\hline
\end{tabular}

Prepared by: José Gavidia, 2016

Table.2 Check list format. GITP001

\begin{tabular}{|c|c|c|c|c|c|c|c|c|}
\hline \multirow{2}{*}{ No. } & \multirow{2}{*}{ PLANES DE MANTENIMIENTO } & \multicolumn{3}{|c|}{ CRITERIO } & \multicolumn{3}{|c|}{$\mathrm{PESO} \%$} & \multirow{2}{*}{ TOTAL } \\
\hline & & $\mathrm{NC}$ & $\mathrm{MC}$ & $\mathrm{AC}$ & 0 & 1 & 2 & \\
\hline 3.1 & $\begin{array}{l}\text { Planes de mantenimiento de la flota } \\
\text { vehicular }\end{array}$ & $X$ & & & 0 & & & 0 \\
\hline 3.2 & Talleres de servicio calficado & & $X$ & & & 1 & & 1 \\
\hline 3.2 .1 & Calboración de herramientas & $X$ & & & 0 & & & 0 \\
\hline 3.2 .2 & Centro de repuestos & & & X & & & 2 & 2 \\
\hline 3.2 .3 & Control de calidad del. Mantenimiento & $X$ & & & 0 & & & 0 \\
\hline 3.3 & Convenio con talleres de servicio & & & X & & & 2 & 2 \\
\hline 3.4 & $\begin{array}{l}\text { Polliticas para el mantenimiento } \\
\text { vehicular }\end{array}$ & $X$ & & & 0 & & & 0 \\
\hline 3.4 .1 & Auditorias del mantenimiento vehicular & $X$ & & & 0 & & & 0 \\
\hline 3.4 .2 & Reistro del mantenimiento vehicular & & & X & & & 2 & 2 \\
\hline 3.4 .3 & Evaluación del cumplimiento & $X$ & & & 0 & & & 0 \\
\hline & TOTAL Plan de Mitto. & $\%$ Actual & 35,00 & & & SUMA & 20 & 7 \\
\hline
\end{tabular}

Made by: José Gavidia, 2016 
Table.3 Interprovincial transport companies taken as samples

\begin{tabular}{|c|c|c|}
\hline No & COMPAÑÍAS DE TRANSPORTE INTERPROVINCIAL & SIGLAS \\
\hline $\mathbf{1}$ & Cooperativa de Transporte PATRIA & $\mathbf{A}$ \\
\hline 2 & Cooperativa de Transporte ALAUSI & B \\
\hline 3 & Cooperativa de Transporte BAÑOS & $\mathbf{C}$ \\
\hline 4 & Cooperativa de Transporte CHIMBORAZO & D \\
\hline 5 & Cooperativa de Transporte CIUDAD DE PIÑAS & $\mathbf{E}$ \\
\hline 6 & Cooperativa de Transporte COLTA & $\mathbf{F}$ \\
\hline 7 & Cooperativa de Transporte ECUADOR EJECUTIVO & $\mathbf{G}$ \\
\hline 8 & Cooperativa de Transporte EL DORADO & $\mathbf{H}$ \\
\hline 9 & Cooperativa de Transporte FLOTA BOLIVAR & $\mathbf{I}$ \\
\hline 10 & Cooperativa de Transporte FLOTA PELILEO & $\mathbf{J}$ \\
\hline 11 & Cooperativa de Transporte OCCIDENTALES & $\mathbf{K}$ \\
\hline 12 & Cooperativa de Transporte RIOBAMBA & $\mathbf{L}$ \\
\hline 13 & Cooperativa de Transporte ÑUCA LLACTA & $\mathbf{M}$ \\
\hline 14 & $\begin{array}{l}\text { Cooperativa de Transporte F.B.I FLOTA BABAHOYO } \\
\text { INTERPROVINCIAL }\end{array}$ & $\mathbf{N}$ \\
\hline 15 & Cooperativa de Transporte TRANSVENCEDORES & $\mathbf{O}$ \\
\hline
\end{tabular}

Made by: José Gavidia, 2016

Table.4 Vehicle maintenance compliance

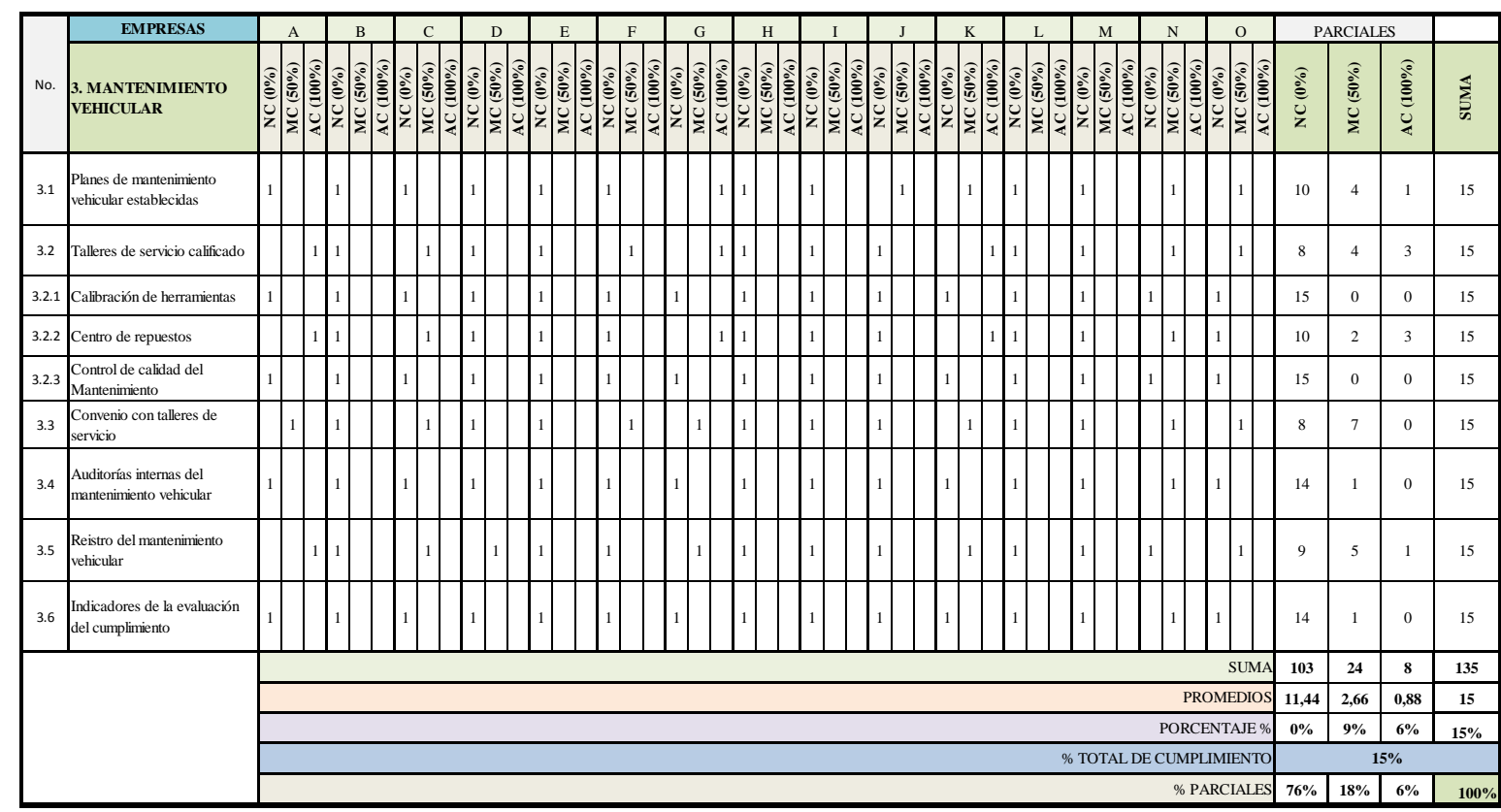

Prepared by: José Gavidia, 2016 
Table.5 Maintenance plan for 100 thousand kilometer

PLAN DE MANTENIMIENTO AUTOBUSES HINO

GITP 004

\begin{tabular}{|c|c|c|c|c|c|c|c|c|c|c|c|c|c|c|c|c|c|c|c|c|c|}
\hline Operaciones de Servicio Km (x 1.000) & UNI & 5 & 10 & 15 & 20 & 25 & 30 & 35 & 40 & 45 & 50 & 55 & 60 & 65 & 70 & 75 & 80 & 85 & 90 & 95 & 100 \\
\hline Cambio de fittro, acete de motor y revision de 18P & Mnu & $\mathrm{R}$ & $\mathrm{R}$ & $\mathrm{R}$ & $\mathrm{R}$ & $\mathrm{R}$ & $\mathrm{R}$ & $\mathrm{R}$ & $\mathrm{R}$ & $\mathrm{R}$ & $\mathrm{R}$ & $\mathrm{R}$ & $\mathrm{R}$ & $\mathrm{R}$ & $\mathrm{R}$ & $\mathrm{R}$ & $\mathrm{R}$ & $\mathrm{R}$ & $\mathrm{R}$ & $\mathrm{R}$ & $\mathrm{R}$ \\
\hline Cambio de fitro de conbustible Primario & Mnu & & $\mathrm{R}$ & & $\mathrm{R}$ & & $\mathrm{R}$ & & $\mathrm{R}$ & & $\mathrm{R}$ & & $\mathrm{R}$ & & $\mathrm{R}$ & & $\mathrm{R}$ & & $\mathrm{R}$ & & $\mathrm{R}$ \\
\hline Cambio de fittro de conbustibe Secundario & Mпu & & & & $\mathrm{R}$ & & & & $\mathrm{R}$ & & & & $\mathrm{R}$ & & & & $\mathrm{R}$ & & & & $\mathrm{R}$ \\
\hline Limpieza del tanque de conbustible & Mnu & & & & & & & & & & 1 & & & & & & & & & & 1 \\
\hline Cambio de acete caja de anbios & Mnu & & & & $\mathrm{R}$ & & & & $\mathrm{R}$ & & & & $R$ & & & & $\mathrm{R}$ & & & & $R$ \\
\hline Cambio aceite de dferencial & Mnu & & & & $\mathrm{R}$ & & & & $\mathrm{R}$ & & & & $\mathrm{R}$ & & & & $\mathrm{R}$ & & & & $\mathrm{R}$ \\
\hline Cambio de aceite de la dreccion hidraulica & Mnu & & & & & & & & & & & & 1 & & & & & & & & 1 \\
\hline Liquido sistema de embrague & Мпи & & & & & & & & & & & & 1 & & & & & & & & \\
\hline Coinete certral del eje trasero & Mnu & $\mathrm{L}$ & $\mathrm{L}$ & $\mathrm{L}$ & $\mathrm{L}$ & $\mathrm{L}$ & $\mathrm{L}$ & $\mathrm{L}$ & $\mathrm{L}$ & $\mathrm{L}$ & $\mathrm{L}$ & $\mathrm{L}$ & $\mathrm{L}$ & $\mathrm{L}$ & $\mathrm{L}$ & $\mathrm{L}$ & $\mathrm{L}$ & $\mathrm{L}$ & $\mathrm{L}$ & $\mathrm{L}$ & $\mathrm{L}$ \\
\hline Grasa abos de rueda (delanteros y traseros) & Mnu & & & & & & & & $\mathrm{L}$ & & & & & & & & $\mathrm{L}$ & & & . & 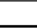 \\
\hline Zapatas de freno & Mnu & & & & $\mathrm{R}$ & & & & $\mathrm{R}$ & & & & $\mathrm{R}$ & & & & $\mathrm{R}$ & & & & $\mathrm{R}$ \\
\hline Grasa Cructas y balineras de Gricnes & Mnu & $\mathrm{L}$ & $\mathrm{L}$ & $\mathrm{L}$ & $\mathrm{L}$ & $\mathrm{L}$ & $\mathrm{L}$ & $\mathrm{L}$ & $\mathrm{L}$ & $\mathrm{L}$ & $\mathrm{L}$ & $\mathrm{L}$ & $\mathrm{L}$ & $\mathrm{L}$ & $\mathrm{L}$ & $\mathrm{L}$ & $\mathrm{L}$ & $\mathrm{L}$ & $\mathrm{L}$ & $\mathrm{L}$ & $\mathrm{L}$ \\
\hline \begin{tabular}{|l} 
Hogura de Valwass \\
\end{tabular} & Mกu & & $\mathrm{R}$ & & & & & & $\mathrm{R}$ & & & & & & & & $\mathrm{R}$ & & & & \\
\hline Elemento de fitro de Aire $^{*}$ & Mnu & & $\mathrm{R}$ & & $\mathrm{R}$ & & $\mathrm{R}$ & & $\mathrm{R}$ & & $\mathrm{R}$ & & $\mathrm{R}$ & & $\mathrm{R}$ & & $\mathrm{R}$ & & $\mathrm{R}$ & & $\mathrm{R}$ \\
\hline Elemento de fitro de Aire Secundario ${ }^{*}$ & Mnu & & & & $\mathrm{R}$ & & & & $\mathrm{R}$ & & & & $\mathrm{R}$ & & & & $\mathrm{R}$ & & & & $\mathrm{R}$ \\
\hline Refrigerarte del notor $=$ & Mnu & & & & & & & & & & & & & & & & $\mathrm{R}$ & & & & \\
\hline Tueras pernos en U (grapas ballestrss $)^{* z z}$ & Mпu & $\mathrm{L}$ & & & $\mathrm{L}$ & & & & $\mathrm{L}$ & & & & $\mathrm{L}$ & & & & $\mathrm{L}$ & & & & $L$ \\
\hline Hojas de balestas (alineacion, fisuras y defornaciones) & Mnu & & & & $\mathrm{L}$ & & & & $\mathrm{L}$ & & & & $\mathrm{L}$ & & & & $\mathrm{L}$ & & & & $\mathrm{L}$ \\
\hline Alineacion de dreccion & Mnu & & & & $\mathrm{R}$ & & & & $\mathrm{R}$ & & & & $\mathrm{R}$ & & & & $\mathrm{R}$ & & & & $\mathrm{R}$ \\
\hline Carrera y juego lbre del pedal def freno & Мпи & 1 & 1 & 1 & 1 & 1 & 1 & 1 & 1 & 1 & 1 & 1 & 1 & 1 & 1 & 1 & 1 & 1 & 1 & 1 & 1 \\
\hline Pernos columna de direccion & Mnu & & & & 1 & & & & 1 & & & & 1 & & & & 1 & & & & 1 \\
\hline Electrolito baterias y rotacion & Mnu & & 1 & & 1 & & 1 & & 1 & & 1 & & 1 & & 1 & & 1 & & 1 & & 1 \\
\hline Estado de los bonbillos & Mnu & 1 & 1 & 1 & 1 & 1 & 1 & 1 & 1 & 1 & 1 & 1 & 1 & 1 & 1 & 1 & 1 & 1 & 1 & 1 & 1 \\
\hline Regular pernotope freno motor & Mnu & & & & 1 & & & & 1 & & & & 1 & & & & 1 & & & & 1 \\
\hline Limpéza / Purga sistema neumatico & Mnu & 1 & 1 & 1 & 1 & 1 & 1 & 1 & 1 & 1 & 1 & 1 & 1 & 1 & 1 & 1 & 1 & 1 & 1 & 1 & 1 \\
\hline & & & & & & & & & & & & & & & & & & & & & \\
\hline
\end{tabular}

Bajc condiciones extremas se debe aumentar al doble la frecuencia de cada oper ación

"Ócada 18 meses

"* Reducir periodo para Volquetas

$\mathrm{R}=\mathrm{Reemplaz0}$

$\mathrm{I}=$ Inspección y/0 limpieza

$\mathrm{L}=$ Lubricacion

Carried out by: José Gavidia, 2016

Table.6 Vehicle maintenance compliance

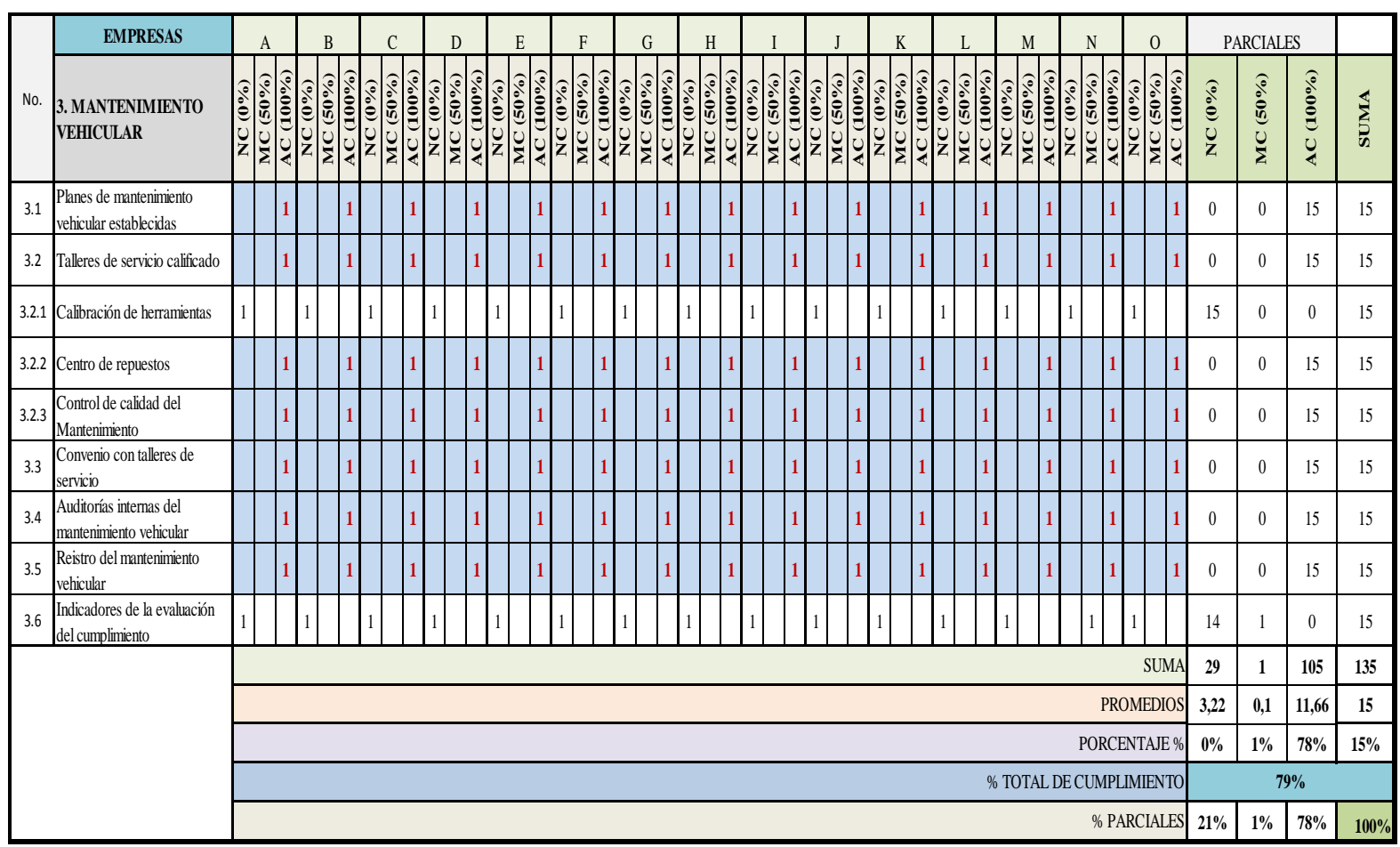

Prepared by: José Gavidia, 2016 
Table.7 Chi square fit test

\begin{tabular}{|c|c|c|c|c|c|c|c|}
\hline Aspectos considerados & $\begin{array}{c}\text { MÉTODO } \\
\text { ACTUAL } \\
(0 \mathrm{i})\end{array}$ & $\begin{array}{c}\text { MÉTODO } \\
\text { PROPUESTO } \\
\text { (Ei) }\end{array}$ & SUMA & TOTAL & $\mathrm{Oi}-\mathrm{Ei}$ & $(0 \mathrm{O}-\mathrm{Ei})^{\wedge} 2$ & $(0 \mathrm{O}-\mathrm{Ei})^{\wedge} 2 / \mathrm{Ei}$ \\
\hline Gestión Administrativa & 4,16 & 9,52 & 13,68 & 26,43 & $-5,36$ & 28,73 & 3,02 \\
\hline Calificación de Conductores & 4,24 & 6,51 & 10,75 & 20,77 & $-2,27$ & 5,15 & 0,79 \\
\hline Mantenimiento Vehicular & 1,48 & 19,44 & 20,92 & 40,43 & $-17,96$ & 322,56 & 16,59 \\
\hline Calidad de Servicio & 0,51 & 5,89 & 6,4 & 12,37 & $-5,38$ & 28,94 & 4,91 \\
\hline TOTAL & 10,39 & 41,36 & 51,75 & 100 & & $x^{\wedge} 2=$ & 25,32 \\
\hline
\end{tabular}

Prepared by: José Gavidia, 2016

Table.8 Critical values of the chi-square distribution

\begin{tabular}{|c|c|c|c|c|c|c|c|c|c|c|c|}
\hline \multirow{2}{*}{$\begin{array}{l}\text { Grados de } \\
\text { libertad }\end{array}$} & \multicolumn{10}{|c|}{ Probabilidad } & \multirow[b]{2}{*}{0,001} \\
\hline & 0,95 & 0,90 & 0,80 & 0,70 & $0,5.0$ & 0,30 & 0,20 & 0,10 & 0,05 & 0,01 & \\
\hline 1 & 0,004 & 0,02 & 0,06 & 0,15 & 0,46 & 1,07 & 1,64 & 2,71 & 3,84 & 6,64 & 10,83 \\
\hline 2 & 0,10 & 0,21 & 0,45 & 0,71 & 1,39 & 2,41 & 3,22 & 4,60 & 5,99 & 9,21 & 13,82 \\
\hline 3 & 0,35 & 0,58 & 1,01 & 1,42 & 2,37 & 3,66 & 4,64 & 6,25 & 7,82 & 11,34 & 16,27 \\
\hline 4 & 0,71 & 1,06 & 1,65 & 2,20 & 3,36 & 4,88 & 5,99 & 7,78 & 9,49 & 13,28 & 18,47 \\
\hline 5 & 1,14 & 1,61 & 2,34 & 3,00 & 4,35 & 6,06 & 7,29 & 9,24 & 11,07 & 15,09 & 20,52 \\
\hline 6 & 1,63 & 2,20 & 3,07 & 3,83 & 5,35 & 7,23 & 8,56 & 10,54 & 12,59 & 16,81 & 22,46 \\
\hline 7 & 2,17 & 2,83 & 3,82 & 4,67 & 6,35 & 8,38 & 9,80 & 12,02 & 14,07 & 18,48 & 24,32 \\
\hline 8 & 2,73 & 3,49 & 4,59 & 5.53 & 7,34 & 9,52 & 11,03 & 13,36 & 15,51 & 20,09 & 26,12 \\
\hline 9 & 3,32 & 4,17 & 5,38 & 6,39 & 8,34 & 10,66 & 12,24 & 14,68 & 16,92 & 21,67 & 27,88 \\
\hline \multirow[t]{2}{*}{10} & 3,94 & 4,86 & 6,18 & 7,27 & 9,34 & 11,78 & 13,44 & 15,99 & 18,31 & 23,21 & 29,59 \\
\hline & \multicolumn{8}{|c|}{ No significativo } & \multicolumn{3}{|c|}{ Significativo } \\
\hline
\end{tabular}

Source: (Mason, 2003)

Table.9 Results

\begin{tabular}{|c|c|}
\hline \multicolumn{2}{|c|}{ RESULTADOS } \\
\hline $\mathbf{X}^{\wedge} \mathbf{2}=$ & $\mathbf{2 5 , 3 2}$ \\
\hline Valor critico $=$ & $\mathbf{1 1 , 3 4}$ \\
\hline
\end{tabular}


Graph.1 Integral homologation model

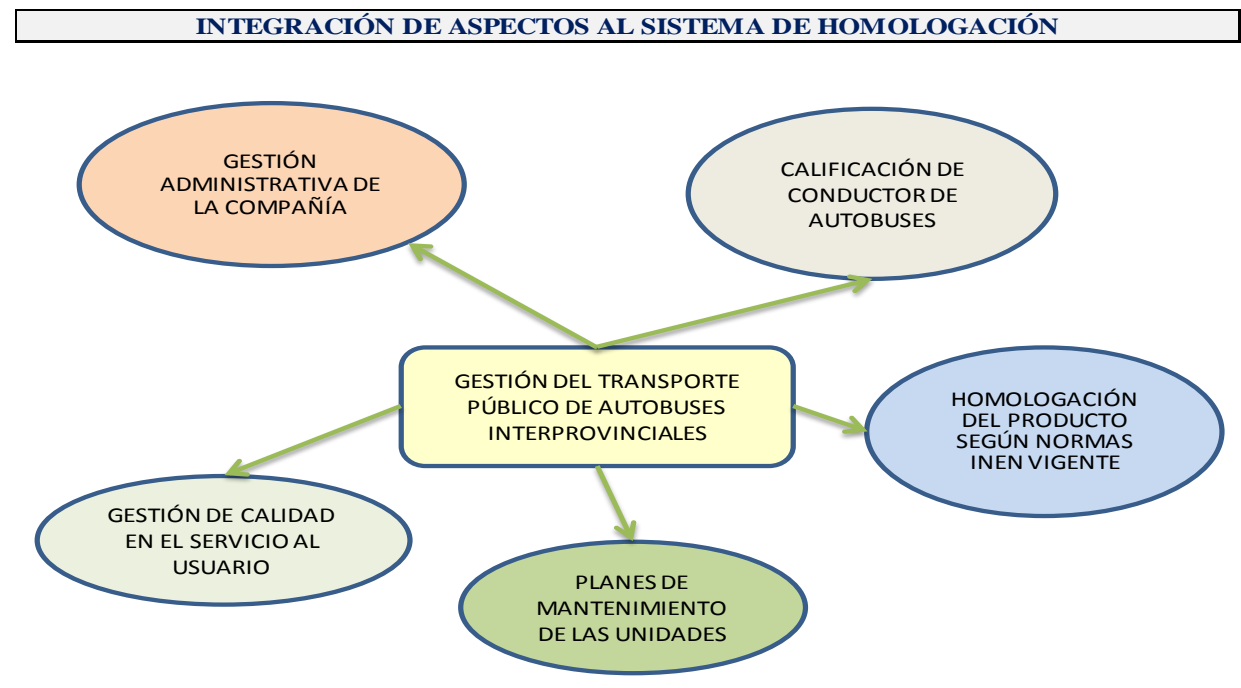

Made by: José Gavidia, 2016

Graph.2 Current situation of the aspects considered in the integral homologation

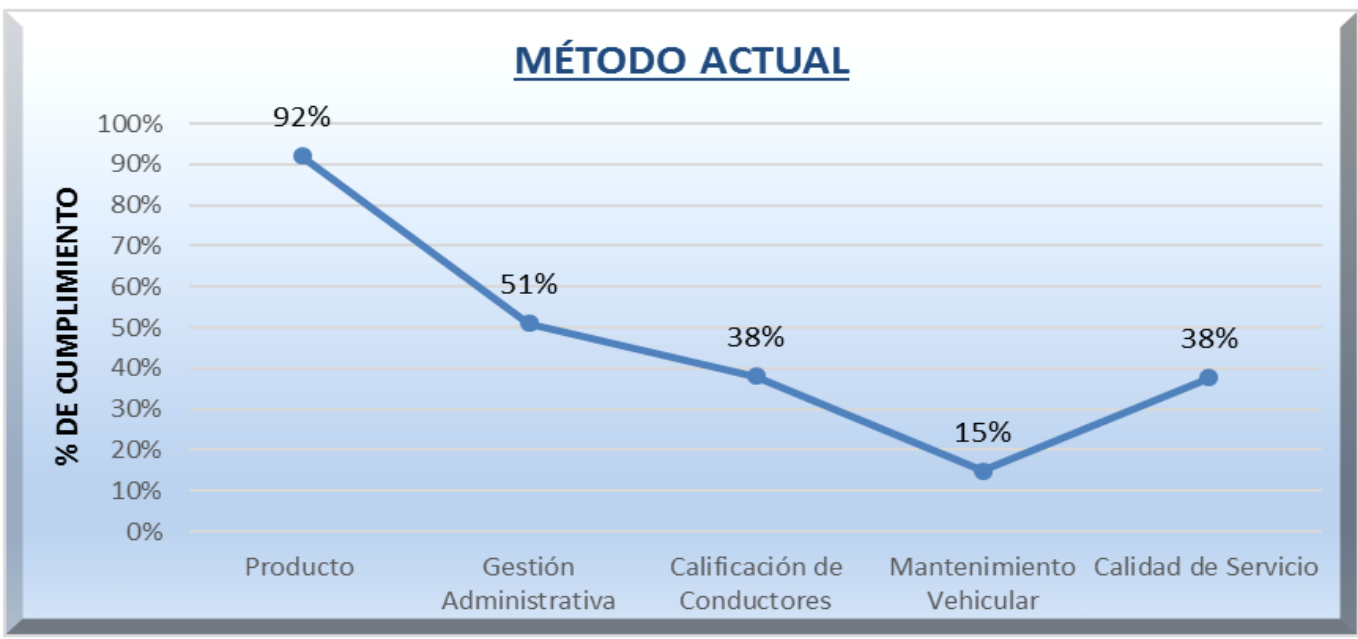

Graph.3 Record and monitoring of human talent

\begin{tabular}{|c|c|c|c|c|c|c|c|c|c|c|c|}
\hline GITP 005 & \multicolumn{11}{|c|}{ REGISTRO Y SEGUIMIENTO DEL TALENTO HUMANO } \\
\hline \begin{tabular}{|l} 
FOTOGRAFÍA \\
\end{tabular} & NOMBRE & EDAD & $\mathrm{C.I}$ & ESTADO CIVIL & FUNCIÓN & DIRECCIÓN & CIUDAD & PERMISOS & VACACIONES & CREDITOS & OBSERVACIONES \\
\hline & & & & & & & & & & & \\
\hline & & & & & & & & & & & \\
\hline & & & & & & & & & & & \\
\hline \begin{tabular}{|l} 
FOTOGRAFíA \\
\end{tabular} & NOMBRE & EDAD & C.I & ESTADO CIVIL & FUNCIÓN & DIRECCIÓN & CIUDAD & PERMISOS & VACACIONES & CREDITOS & OBSERVACIONES \\
\hline & & & & & & & & & & & \\
\hline & & & & & & & & & & & \\
\hline & & & & & & & & & & & \\
\hline FOTOGRAFÍA & NOMBRE & EDAD & C.I & ESTADO CIVIL & FUNCIÓN & DIRECCIÓN & CIUDAD & PERMISOS & VACACIONES & CREDITOS & OBSERVACIONES \\
\hline & & & & & & & & & & & \\
\hline & & & & & & & & & & & \\
\hline & & & & & & & & & & & \\
\hline
\end{tabular}

Realized by: Jose Gavidia, 2016 
Graph.4 General Results

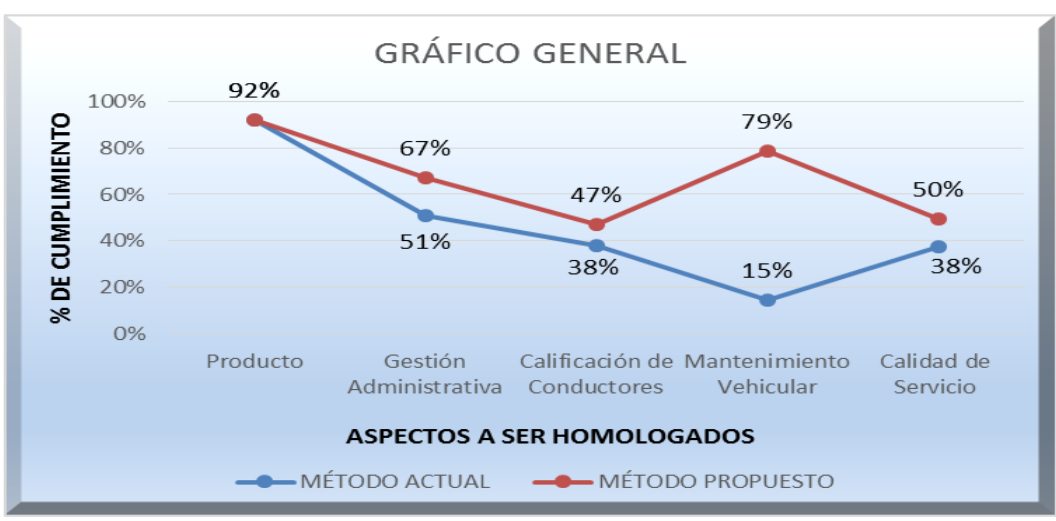

\section{Graph.5}

FACTOR JI CUADRADA

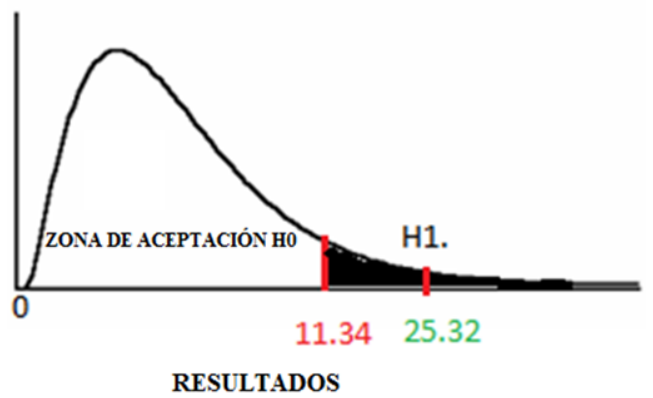

3. MANTENIMIENTOVEHICULAR

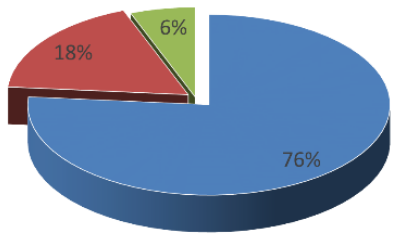

Evaluating the current situation of each one of the aspects considered in the integral homologation shows the following behavior

\begin{tabular}{|l|c|}
\hline \multicolumn{1}{|c|}{ Aspectos considerados } & MÉTODO ACTUAL \\
\hline Producto & $92 \%$ \\
\hline Gestión Administrativa & $51 \%$ \\
\hline Calificación de Conductores & $38 \%$ \\
\hline Mantenimiento Vehicular & $15 \%$ \\
\hline Calidad de Servicio & $38 \%$ \\
\hline
\end{tabular}


Current method

\section{MANTENIMIENTO VEHICULAR}

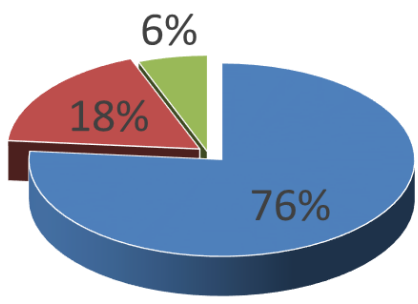

$\because \mathrm{NC} \square \mathrm{MC} \square \mathrm{AC}$

Current method

\section{GESTIÓN ADMINISTRATIVA}

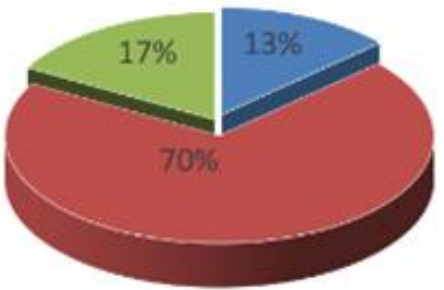

$=N C \quad=M C \quad=A C$

Current method

2. CALLFICACIÓN DE CONDUCTORES

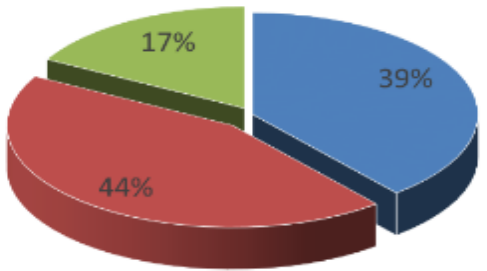

$=\mathrm{NC}=\mathrm{MC}=\mathrm{AC}$
Proposed method

\section{MANTENIMIENTO VEHICULAR}

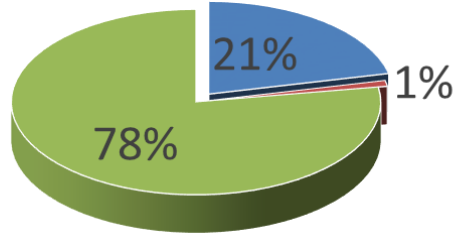

$\square \mathrm{NC} \backsim \mathrm{MC} \square \mathrm{AC}$

Proposed method

1. GESTIÓN ADMINISTRATIVA

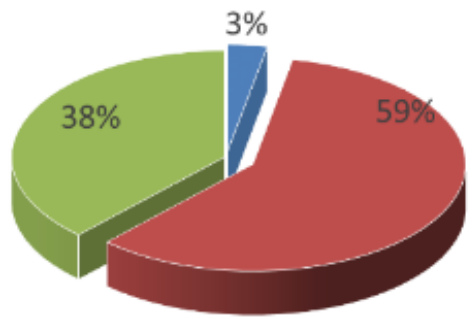

$=\mathrm{NC} \quad \mathrm{MC} \quad \mathrm{AC}$

Proposed method

2. CALIFICACIÓN DE CONDUCTORES

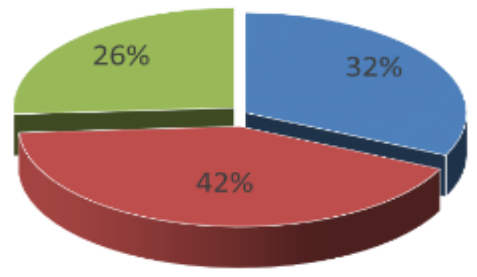

$=\mathrm{NC}=\mathrm{MC}=\mathrm{AC}$
Current method

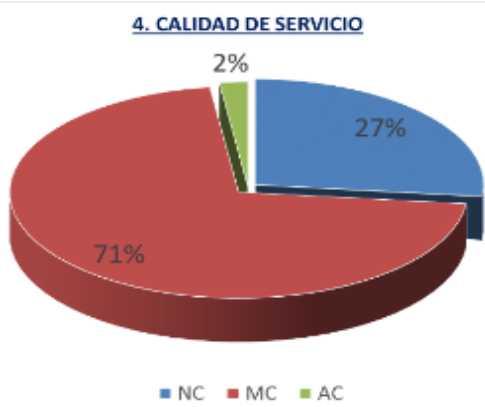

Proposed method

4. CALIDAD DE SERVICIO




Skills

Experience

Driver's license to order

Selection and recruitment procedure

Practical tests

Theoretical knowledge tests

Psychometric tests

Socio-economic condition of the driver

\section{Quality of service}

With respect to the quality of service based on the criteria of the users.

Quality of service policy

Training plans

Good attitude of the service personnel

Handling complaints and claims

Excellent performance in the moments of truth

Suggestion box

Response time limit

Suitable facilities

Bathrooms in perfect condition

Adequate waiting room

Cargo and baggage hold

Signage

Compliance evaluation according to internal policy

Based on the parameters evaluated, the technical methodology for the homologation was established, consisting of established and standardized parameters and policies that must be carried out effectively, in order to improve the efficiency of the public transport service in Ecuador.

\section{Results and Discussion}

The obtaining of the results, is based on the use of the qualification criterion, in which the weights according to compliance are shown, which are shown in table 2.

\section{Vehicle maintenance}

Obtaining the unique homologation certificate for vehicle maintenance proposes the following maintenance plan for one hundred thousand kilometers.

With the application of the proposal, vehicle maintenance was evaluated, obtaining considerable results. In this indicator, the highest percentage of variability can be observed, that is, this aspect has a greater impact on improvement.

\section{Administrative management}

It is proposed a format for the registration and monitoring of human talent that are part of the public transport companies of interprovincial buses.

The current method was compared with the proposed method based on the technical methodology for integral homologation.

\section{Drivers qualification}

Through the graph it is observed that the technical methodology generates a positive result in terms of compliance, the qualification of the driver is very important for a service of quality and safety, however, there are opportunities for improvement, although this one shows the lowest percentage of variability.

\section{Quality of service}

This intangible aspect is the one that most impacts the user since it is the result of direct contact with the server.

\section{General result}

Next, we can observe the current situation of the interprovincial public transport cooperatives and how it influences the result through the proposal.

The integral homologation positively influences the safety and quality of service to the user, since as can be seen the four categories considered in this study, show a positive variation.

It is observed that there is an improvement in the four aspects evaluated, mainly in the management of vehicle maintenance.

This factor is important since the safety of drivers and users depends on them, such as the durability of the vehicles, reduction of maintenance costs, obtaining satisfactory results from companies and users.

With the proposal and with the data obtained, the hypothesis was evaluated by the chi square method.

$\chi^{2}=\sum_{i=1}^{k} \frac{\left(O_{i}-E_{i}\right)^{2}}{E_{i}}$.

With $10 \%$ of the level of significance and three (3) degrees of freedom, it is possible to find the critical value 
associated using the table of chi-square distribution values. If the calculated value is less than the limit chosen by the statistical significance in the table of the chi-square distribution, then the null hypothesis is rejected in favor of the alternative hypothesis.

In such a way that, when taking the critical value, with degree of significance of 0.1 and with three (3) degrees of freedom, we have in table 8 .

Then: $11.34<25.32$ calculated

Therefore, the null hypothesis is rejected, in favor of the alternative hypothesis that mentions:

H1: The Integral Homologation positively influences the security and quality of service to the user.

H0: The Integral Homologation DOES NOT have a positive effect on the safety and quality of service to the user.

The proposal of the technical regulation for the Integral Homologation developed, establishes the union of the important aspects immersed in the interprovincial public transport system, since, in addition, they are linked to each other, to guarantee security and quality of service to the user.

The methodology designed in the proposal of the technical regulation for the integral homologation of the interprovincial public transport, contributes to: improve the administrative management, improve the quality of service to the user, improve the control and compliance of the vehicular maintenance and better selection and development of the human talent specifically the drivers and their companions.

With the evaluations made, there are opportunities for improvement in the Administrative Management, in the human talent specifically in the Drivers, in the Vehicle Maintenance, and in the quality of service to the client, which together would indicate that there is no structure that manages all these aspects, this has led to an inadequate interprovincial public transport service, not guaranteeing the safety and quality of service to the user.

Combined methodologies such as the Maintenance Plan, Evaluation of objectives and development of human talent, are relatively easily adapted to the context of integral homologation, obtaining a more efficient, reliable and efficient service.

\section{Recommendations}

Given the development of this basic research work, it opens several opportunities to develop research projects such as: adaptation to other modes of transport, be they urban, school, intraprovincial, among others.

Make use of this proposal under strict responsibility and compliance of each member of interprovincial public transport companies, to obtain positive results and consideration.

Once the management model for the integral homologation of public transport of interprovincial buses has been developed, all transport companies of this modality should be socialized, starting first at the provincial level and after an evaluation, it can be taught at the national level.

A more robust system is recommended based on this proposal based on other standardized procedures of interest to the sector.

\section{References}

Chase, R. \& Jacobs, R. \& Aquilano, N. (2006). Operations management, 12 va. Edition, Mc Graw Hill. p (6).

Godoy, J. (2011). Human capital in customer service and quality of service. Redalyc.org. 4 (8). 25 - 30.

Hernández, R. Fernández, C. \& Baptista, P. (2010). Research methodology. Bogotá Mc Graw Hill.

http://www.ant.gob.ec/old/ index.php/vehicular homolog ation.

http://www.ciencia.cl/ CienciaAlDia/volumen2/numero1 / articles / articulo2.html

http://www.scielo.org.ar/ scielo.php? script = sci_arttext $\&$ pid $=$ S1851-17162010000200001

http://www.scielo.org.co/ scielo.php? script = sci_arttext $\&$ pid = S0121-47722012000300009

Mason, Lind \& Marchal. (2003). Statistics for administration and economy. Bogotá Alpha Omega. Tenth edition.

Moliner, C. (2001). Quality of service and customer satisfaction. Redalyc.org. 17 (2). 233-235.

NTE INEN 2 205: 2010, Ecuadorian technical regulations for road vehicles, motor vehicles, urban bus, requirements. First edition.

Padilla, C. (2012). Maintenance management plan for the decentralized autonomous government vehicle fleet of the city of Cañar. Ecuador basin 
Pro-Ecuador. (28 of 06 of 2015). Application documents within the vehicle homologation process. Recovered from.

Resolution 081-DIR-2015-ANT. (2015). retrieved from www.ant.gob.ec ;

Rodriguez, J. (2011). Qualitative research methods. Syllogism research journal.

\section{How to cite this article:}

José Luis Gavidia García, Eddy Stalin Alvarado Pacheco and Luis Alfonso Condo Plaza. 2018. Technical Methodology for the Integral Homologation of the Public Transport of Interprovincial Buses. Int.J.Curr.Res.Aca.Rev. 6(7), 25-41. doi: https://doi.org/10.20546/ijcrar.2018.607.004
Sampieri, R. (2007). Fundamentals of research methodology. Mexico. Mc Graw Hill.

Supplement RO, 475. (2011). Ecuadorian School Transportation Regulations, Quito, Ecuador:

Tobar, E. (2001). Quality of Service and Development Person. Caracas, Venezuela: Universal 